\title{
PEMBERDAYAAN PEREMPUAN PESISIR DALAM PENGELOLAAN IKAN ASAP DI KABUPATEN BUTON UTARA
}

\author{
Muh. Askal Basir, ${ }^{1}$ Hardin, ${ }^{2}$ Cecep Nuryadin ${ }^{3}$ \\ ${ }^{1}$ Fakultas Ilmu Sosial dan Ilmu Politik Universitas Muhammadiyah Buton Jl. \\ Betoambari No. 36 Kota Baubau, 93721, Indonesia.. \\ ${ }^{2}$ Fakultas Pertanian Universitas Muhammadiyah Buton Jl. Betoambari No. 36 \\ Kota Baubau, 93721, Indonesia. \\ ${ }^{3}$ Fakultas Keguruan dan Ilmu Pendidikan Universitas Muhammadiyah Buton Jl. \\ Betoambari No. 36 Kota Baubau, 93721, Indonesia \\ Email: $\underline{\text { muh.askal@umbuton.ac.id }}$
}

\begin{abstract}
Abstrak
Tujuan penelitian ini adalah untuk mengetahui bagaimana Pemberdayaan Perempuan Pesisir dalam Pengelolaan Ikan Asap di Desa Malalanda Kecamatan Kulisusu Kabupaten Buton Utara Metode pendekatan yang digunakan untuk mengatasi berbagai persoalan yang dihadapi adalah dengan cara pendekatan partisipatif aktif dengan Prosedur Kerja adalah sebagai berikut yaitu 1) Tahap persiapan adalah Koordinasi pelaksanaan program 2) Tahap pelaksanaan, yaitu berupa penyuluhan/pelatihan/workshop 3) Tahap monitoring dan evaluasi, yaitu dilakukan pendampingan dan penilaian atas capaian program yang telah dilaksanakan. Hasil Pengabdian ini adalah: (1) Persiapan Pemberdayaan Masyarakat perempuan pesisir yaitu dengan melakukan koordinasi baik itu dengan pemerintah daerah dan masyarakat pesisir yang akan jadi objek pemberdayan serta menyiapkan sarana dan prasarana yang menunjang pelaksanaan pemberdayaan (2) pelaksanaan Workshop dengan memberikan keterampilan kepada perempuan di wilayah pesisir yang akan menjalani proses belajar tentang pengetahuan dan keterampilan dengan pengolahan menjadi ikan asap yang berasal dari olahan hasil laut agar lebih bernilai jual serta memberikan penyuluhan penguatan kelembagaan dengan mengoptimalkan Koperasi Simpan Pinjam bagi masyarakat yang berada di kawasan pesisir karena koperasi ini berfungsi sebagai tempat untuk menggali dan mengaktualkan potensi ekonomi lokal guna merangsang tumbuhnya peluang kerja, kesempatan berusaha (3) monitoring dan evaluasi dengan mengadakan pendampingan usaha yaitu dapat membantu dalam meningkatkan kesadaran dan pengetahuan, kemauan serta motivasi untuk meningkatkan usaha dan membantu menemukan inovasi baru sehingga produk usah dapat memiliki daya saing.
\end{abstract}

Kata Kunci: Pemberdayaan, Perempuan Pesisir, Ikan Asap 


\section{A. Pendahuluan}

Pesisir adalah wilayah yang unik, karena dalam konteks bentang alam, wilayah pesisir merupakan tempat bertemunya daratan dan lautan (Vitayala, 2001). Wilayah pesisir merupakan wilayah yang penting apabila ditinjau dari berbagai sudut pandang perencanaan dan pengelolaan. Transisi antara daratan dan lautan di wilayah pesisir telah membentuk ekosistem yang beragam dan sangat produktif serta memberikan nilai ekonomi yang luar biasa terhadap manusia. Sejalan dengan pertambahan penduduk dan peningkatan kegiatan pembangunan sosial-ekonomi, nilai wilayah pesisir terus bertambah. Konsekuensi dari tekanan terhadap pesisir ini adalah masalah pengelolaan yang timbul karena konflik pemanfaatan yang timbul akibat berbagai kepentingan yang ada di wilayah pesisir.

Pada hakekatnya perempuan adalah sumberdaya insani yang memiliki potensi yang dapat didayagunakan dalam berbagai bidang dan sektor pembangunan nasional. Populasi penduduk perempuan Indonesia yang cenderung bertambah terus, pada sisi tertentu sering di pandang sebagai masalah kependudukan. Namun pada sisi lain justru memandang populasi penduduk perempuan ini sebagai masalah kependudukan. Wanita merupakan suatu potensi, dimana saat ini dalam persaingan global yang semakin menguat dan ketat, maka program pemberdayaan wanita menjadi sangat penting dalam menjawab berbagai tantangan sekaligus memanfaatkan peluang dimasa yang akan datang. Posisi wanita yang selama ini cenderung diletakkan lebih rendah daripada laki-laki, menyebabkan kemampuan wanita untuk berkontribusi dan mengembangkan potensi tidak maksimal.

Fenomena perempuan bekerja bukan lagi barang aneh dan bahkan dapat dikatakan sudah merupakan tuntutan bagi perempuan untuk berpartisipasi dalam dunia kerja, yang dapat menaikkan harkat perempuan, yang sebelumnya selalu di anggap hanya sebagai pengurus anak, suami dan rumah tangga semata- mata. Bahkan sebelumnya banyak gagasan dan strereotip tentang perempuan sebagai omongan yang acuh tak acuh pada lingkungan, bodoh dan kurang memiliki kemampuan yang akhirnya merendahkan martabat perempuan (Hikmat, 2001). 
Sebagaimana kita ketahui bahwa dalam perempuan memiliki peranan yang sangat besar dalam pembangunan. Perempuan memiliki kemampuan untuk menyususn rencana dan menjalankan tugas dengan kualitas yang tidak kalah dari kaum pria. Bahkan dalam dunia teknologi banyak kaum perempuan yang sudah menunjukkan prestasinya. Dalam berbagai bidang perempuan telah berpartisipasi, misalnya di bidang kesehatan, bidang pemerintahan dan sebagainya.

Perempuan yang mendapatkan bimbingan dan arahan yang tepat, khususnya perempuan yang terdapat di pesisir pantai akan menjadi tenaga kerja yang berkualitas tinggi. Misalnya memberi pelatihan dalam pengolahn berbagai hasil tangkapan dari laut. Dengan berperannya perempuan, selain menjadi tiang dalam rumah tangga, sebagai insane pendidik anak-anaknya, perempuan juga dapat menopang perekonomian keluarga. Dari seorang perempuan yang memiliki kualitas pengetahuan yang baik, akan terlahir generasi bangsa yang berkualitas pula. Ini berarti perempuan memiliki peranan yang cukup besar dalam pembangunan.

Namun dalam aplikasinya, kesempatan bagi perempuan untuk mendapatkan pendidikan, bantuan kredit sampai pada pengenalan teknologi, masih sangat jauh dibandingkan dengan kesempatan yang diperoleh kaum pria. Sejalan dengan perkembangan teknologi dan informasi yang tidak berbatas, perempuan di perkotaan mulai menyadari ketertinggalannya. Kesadaran ini mendorong kaum perempuan untuk memperjuangkan haknya dalam mengaktualisasikan dirinya agar lebih berperan dan mendapat akses yang seimbang di segala bidang pembangunan. Sebaliknya perkembangan tersebut relatif lambat untuk wanita yang tinggal di pedesaan terutama daerah pesisir, karena keterbatasan fasilitas umum yang tersedia, seperti informasi dan sentuhan teknologi, sehingga aktualisasinya dalam pembanguan masih jauh dari harapan. Tentunya dibutuhkan perhatian dan tindakan nyata dari pihak yang bersangkutan untuk menghadapi masalah ini. Sehingga segala potensi perempuan daerah pesisir dapat dikembangkan demi kemajuan bangsa umumnya dan kemajuan daerah pesisir khususnya. 
Dengan keadaan perempuan pesisir di Desa Malalanda yang masih belum memiliki kemampuan yang dapat menopang usaha keluarga, terkadang hasil tangkapan ikan yang melipah dari suami mereka tidak dapat terjual semuanya dan tidak dimanfaatkan dengan baik. Oleh karena itu agar bisa menjadi usaha yang produktif maka perlu upaya pemberdayaan bagi pempuan pesisir tersebut.

Pemberdayaan perempuan di desa malalanda Kecamatan Kulisusu yaitu melalui pemberian keterampilan dengan mengolah hasil perikanan laut yaitu dengan mengolah tangkapan ikan tongkol menjadi ikan asap. Tujuan dari pemberdayaan tersebut bagi perempuan pesisir diharapkan dapat meningkatkan keterampilan dalam mengolah hasil laut, sehingga kelak dapat meningkatkan usaha-usaha produktif hasil laut dari suaminya sendiri serta berperan dalam membantu pendapatan untuk mencukupi pemenuhan kebutuhan keluarga. Tujuan pengabdian ini adalah untuk mengetahui bagaimana Pemberdayaan Perempuan Pesisir dalam Pengelolaan Ikan Asap Pada Wilayah Pesisir di Desa Malalanda Kecamatan Kulisusu Kabupaten Buton Utara

\section{B. Masalah}

Mengacu pada butir analisis tersebut di atas, persoalan yang dihadapi oleh perempuan pesisir Desa Malalanda Kecamatan Kulisusu adalah

a. Permasalahan terkait dengan keteampilan:

1) Belum adanya keterampilan mengolah hasil perikanan laut.

2) Belum andanya manajemen yang dijalankan dalam melakukan usaha.

b. Permasalahan terkait kelembagaan

1) Pempuan pesisir Desa Malalanda belum memiliki kelembagaan.

2) Pempuan pesisir Desa Malalanda belum mengenal cara menjalankan usaha yang baik.

\section{Metode Pelaksanaan}

Pengabdian ini menggunakan pendekatan partisipatif dengan pertimbangan bahwa pelibatan aktif subyek pengabdian merupakan faktor yang penting untuk menentukan program yang tepat sasaran, berorientasi praktis, pemberdayaaan dan berkelanjutan (Djohani dalam Poerwandari, 2009). 
Tahanpan yang dilakukan dalam metode pendekatan ini didasarkan dalam 3 tahapan yaitu:

a. Tahap persiapan,

Koordinasi pelaksanaan program, pada tahap ini akan dilakukan persiapanpersiapan yang berhubungan dengan pelaksanaan program, penyuluhan, pelatihan dan workshop

b. Tahap pelaksanaan, Pelaksanaan program sesuai dengan kesepakatan yaitu berupa penyuluhan/pelatihan/ workshop antara lain:

1) Pelaksaanaan workshop pembuatan ikan Asap dan Abon Ikan

2) Penyuluhan penguatan kelembagaan dan peningkatan kualitas dan kuantitas produk

3) Memberikan pelatihan Manajemen Usaha kepada perempuan pesisir Desa Malalanda;

c. Tahap monitoring dan evaluasi,

Pada tahap ini dilakukan pendampingan dan penilaian atas capaian program yang telah dilaksanakan.

\section{Pembahasan}

Pemberdayaan Perempuan Pesisir pada Desa Malalanda Kecamatan Kulisusu dilakukan dengan:

a. Tahap Persiapan

Persiapan Pemberdayaan perempuan pesisir yaitu dengan melakukan koordinasi baik itu dengan pemerintah daerah dan masyarakat pesisir yang akan jadi objek pemberdayan serta menyiapkan sarana dan prasarana yang menunjang pelaksanaan pemberdayaan.

b. Tahap Pelaksanaan

1) Pelaksanaan Workshop pembuatan Ikan Asap

a) Penentuan Sasaran

Masyarakat merupakan faktor yang penting dalam kegiatan pemberdayaan, tanpa adanya masyarakat maka kegiatan workshop dalam pemberdayaan tidak dapat berjalan. Sasaran dari program 
pemberdayaan yaitu perempuan pesisir. Program pemberdayaan tersebut dimaksudkan untuk mengembangkan potensi yang ada pada diri perempuan pesisir sesuai dengan kemampuan SDMnya. Setiap individu mempunyai potensi yang harus dikembangkan, begitu pula para perempuan pesisir di desa Malalanda.

Alasan pemilihan sasaran perempuan pesisir sebagai masyarakat yaitu dengan melihat kondisi perempuan pesisir di desa Malalanda yang hanya sebagai ibu rumah tangga biasa/pengangguran. Hal tersebut terjadi karena tingkat pendidikan yang rendah dari perempuan pesisir. Dalam kehidupan sehari-hari saja para perempuan pesisir hanya bergantung pada suami.

b) Pelaksanaan Workshop

Program yang diselenggarakan dalam kegiatan pemberdayaan perempuan pesisir yaitu mengolah dari hasil laut dalam rangka optimalisasi peran perempuan dalam meningkatkan pendapatan rumah tangga. Pemberdayaan yang dilakukan adalah melibatkan perempuan dalam kegiatan ekonomi produktif. Program yang dilakukan dalam workshop ini yaitu sebagai berikut pembuatan ikan asap serta usaha jasa yang mendukung seperti penyediaan sarana produksi lainnya.

Penyelenggara memilih program pembuatan ikan asap tersebut karena pertimbangan letak daerah perempuan pesisir yaitu di kawasan pesisir, supaya nantinya mudah menemukan bahan baku pembuatan produk tersebut. Dan mudahnya ditemukan narasumber dalam pembuatan produk-produk tersebut yang nantinya dapat dijadikan acuan untuk para perempuan pesisir dalam mengembangkan hasil usahanya.

Tahap pertama atau tahap penyadaran dan pembentukan perilaku merupakan tahap persiapan dalam proses pemberdayaan masyarakat. Pada tahap ini sebagai pihak pemberdaya atau pelaku pemberdayaan berusaha menciptakan prakondisi untuk memfasilitasi berlangsungnya proses pemberdayaan yang efektif. 
Tahap kedua yaitu pemberian keterampilan. Perempuan diwilayah pesisir akan menjalani proses belajar tentang pengetahuan dan keterampilan. Dalam hal ini keterampilan yang diajarkan yaitu pengolahan ikan menjadi Ikan Asap yang kesemuanya berasal dari olahan hasil laut agar lebih bernilai jual. Selama ini perempuan di wilayah pesisir Malalanda hanya ikut menjualkan ikan hasil dari tangkapan suami mereka, padahal sebenarnya hasil dari laut tersebut dapat dijadikan lahan usaha.

2) Penyuluhan Penguatan Kelembagaan

Dalam proses pemberdayaan perempuan yang dilakukan di kawasan pesisir Desa Malalanda dalam upaya penguatan kelembagaan dilakukan dengan mengoptimalkan peran Koperasi Simpan Pinjam dengan tujuan agar dalam pelaksanaan usaha yang dilakukan oleh perempuan dikawasan pesisir desa Malalanda tidak terkendala masalah permodalan.

Penguatan kelembagaan dengan mengoptimalkan Koperasi Simpan Pinjam sangat masyarakat yang berada di kawasan pesisir karana koperasi ini berfungsi sebagai tempat untuk menggali dan mengaktualkan potensi ekonomi lokal guna merangsang tumbuhnya peluang kerja, kesempatan berusaha dan Peningkatan akses permodalan yang sangat membatu masyarakat utamanya perempuan sehingga bisa mandiri serta tidak lagi bergantung pada suami.

c. Tahap monitoring dan evaluasi

Pada tahap ini dilakukan pendampingan terhadap kegiatan yang telah dilkukan. Keberadaan pendamping memang dirasakan sangat dibutuhkan dalam setiap program pemberdayaan. Masyarakat belum dapat berjalan sendiri mungkin karena kekurangtauan, tingkat penguasaan ilmu pengetahuan yang rendah, atau mungkin masih kuatnya tingkat ketergantungan mereka karena belum pulihnya rasa percaya diri mereka akibat paradigma-paradigma pembangunan masa lalu. Terlepas dari itu semua, peran pendamping sangatlah vital terutama mendapingi masyarakat 
menjalankan aktivitas usahanya. Namun yang terpenting dari pendampingan ini adalah menempatkan orang yang tepat pada kelompok yang tepat pula.

Oleh karena itu pendampingan usaha dapat membantu dalam meningktan kesadaran dan pengetahuan serat kemauan serta motivasi untuk meningktkan usaha dan membantu menumaka inovasi baru sehingga produk usah dapat memiliki daya saing.

\section{E. Kesimpulan}

Berdasarkan pembahasan diatas maka dapat ditarik kesimpulan sebagai berikut:

1. Persiapan Pemberdayaan Masyarakat perempuan pesisir yaitu dengan melakukan koordinasi baik itu dengan pemerintah daerah dan masyarakat pesisir yang akan jadi objek pemberdayan serta menyiapkan sarana dan prasarana yang menunjang pelaksanaan pemberdayaan.

2. Pelaksanaan Workshop dengan memberikan keterampilan pengolahan ikan menjadi Ikan Asap agar lebih bernilai jual serta memberikan penyuluhan Penguatan Kelembagaan dengan mengoptimalkan Koperasi Simpan Pinjam karana koperasi ini berfungsi sebagai tempat untuk menggali dan mengaktualkan potensi ekonomi lokal guna merangsang tumbuhnya peluang kerja, kesempatan berusaha

3. Monitoring dan evaluasi dengan mengadakan pendampingan usaha yaitu dapat membantu dalam meningkatan kesadaran, pengetahuan, kemauan serta motivasi untuk meningkatkan usaha dan membantu menemukan inovasi baru sehingga produk usaha dapat memiliki daya saing. 


\section{DAFTAR PUSTAKA}

Hikmat.2001. Strategi Pemberdayaan Masyarakat. Bandung: Humaniora. Utama

Poerwandari, E. Kristi. 2009. Pendekatan Kualitatif. Cetakan ketiga. Depok: Lembaga Pengembangan Sarana Pengukuran dan Pendidikan Psikologi Fakultas Psikologi UI

Sajogyo.1993. Pemberdayaan Masyarakat dan Intervensi Komunitas. Jakarta: Lembaga Penerbit FE UI

Sulistiyani, 2004. Kemitraan dan Model-model Pemberdayaan Masyarakat. Yogyakarta: Gava Media

Vitayala, 2001. Pengelolaan Wilayah Pesisir Secara Terpadu. Penerbit CV. Informatika. Bandung 